\title{
Potential Yield Reduction of Sweet and Glutinous Corn Varieties Damaged by The Invasive Pest Spodoptera frugiperda (J.E. Smith) (Lepidoptera: Noctuidae): Field Trial Scale
}

\author{
Anak Agung Ayu Agung Sri Sunari ${ }^{1}$, I Ketut Sumiartha ${ }^{1}$, I Wayan Supartha ${ }^{1, *}$, I G \\ Febri Mahaputra $^{2}$, I Kadek Wisma Yudha ${ }^{3}$, I Wayan Eka Karya Utama ${ }^{3}$, Putu \\ Angga Wiradana ${ }^{4}$ \\ ${ }^{1}$ Laboratory of Integrated Pest Management (IPMLab), Faculty of Agriculture, Udayana University, Denpasar City, \\ Indonesia \\ ${ }^{2}$ Graduate Program of Dryland Agriculture, Faculty of Agriculture, Udayana University, Denpasar City, Indonesia \\ ${ }^{3}$ Doctoral student of Agriculture Science, Faculty of Agriculture, Udayana University, Denpasar City, Indonesia \\ ${ }^{4}$ Study Program of Biology, Faculty of Health, Science and Technology, Universitas Dhyana Pura, Badung Regency, \\ Bali Indonesia \\ *Corresponding author. Email: yansupartha@yahoo.com
}

\begin{abstract}
The aim of this study is to assess the extent of attack and the potential for decreased production of maize types in the field caused to Spodoptera frugiperda. This study was carried out on a large scale, with four treatments and six replications (10 systematic sample replications). Parameters observed include population development, attack rate, the potential for production decline. The results show that this pest attack began to be found in maize 2 weeks after planting (wap) with an average population of 5.37 individu on sweet corn and 6.53 individu on glutinous corn. Furthermore, the population continued to increase up to 5 wap and lowering again to 8 wap. The regression analysis revealed a positive relationship between the larval population and the S. frugiperda attack rate. Sweet corn production decreased by 28.08 percent and glutinous corn output decreased by 25.04 percent, respectively. Overall, our results showed that $S$. frugiperda attacks continued to increase in both maize varieties (glutinous and sweet), which was indicated by an increase in population and a decrease in production on a field trial scale.
\end{abstract}

Keywords: new invasive pest, the fall armyworm, maize varieties, Bali Province.

\section{INTRODUCTION}

Maize (Zea mays L.) originally came from Central America and then spread to various tropical and subtropical areas around the world [1]. With a total production of 18,511 tons in 2013, Indonesia is one of the Southeast Asian nations that produces the most maize among Asean member countries [2]. The use of maize plants in Indonesia apart from being a source of food for the community is also used as animal feed. Almost all parts of the maize plant can be used for various purposes, such as making fertilizer, firewood, and paper materials [3].
Spodoptera frugiperda, or Fall Armyworm J.E. Smith (Lepidoptera: Noctuidae) is a significant maize pest and a polyphagous insect pest that affects over 80 crops. S. frugiperda initially mainly attacked maize fields in subtropical places such as America, causing severe losses. This pest was discovered in Africa for the first time in January 2016. Furthermore, in 2018, this insects expanded to other nations such as India and Yemen [4]. This pest was reported in maize plants in Sumatra, Indonesia, in early 2019. The larval species of $S$. frugiperda caused 60 percent damage to sweet hybrid maize in Petir Village, Dramaga, Bogor Regency, East Java [5]. 
The losses recorded in African and European nations as a result of this insect invasion on maize crops varied from 8.3 to 20.6 million tons per year, with an economic loss value ranging from 2.5 to 6.2 billion US dollars per year. Therefore, this pest has received serious attention by developing countries in ASEAN and Asia-Pacific [6]. This pest attacks maize plants from a young age (vegetative) to the flowering phase (generative) [7]. Symptoms of attack on the shoots of the affected plant appear to be hollow, and there are many larval feces. Characteristics of attacks that appear on the leaves of corn, it will be clear that the damaged parts, holes, and generally the larvae are at the growing point of the corn plant [6].

Sweet corn is a popular horticultural commodity among the general public due to its sweet flavor [8]. However, national sweet corn productivity remains low, with an average of 8.31 tons/ha, despite the fact that the yield potential ranges between 14 and 18 tons/ha [9]. Furthermore, glutinous corn is one of the horticultural commodities that has a high amylopectin content and has a soft and fluffier texture [10]. Likewise, the productivity of glutinous corn is still low at 2 tons/ha [11].

Glutinous and sweet corn varieties have great potential to be produced, especially in the province of Bali. However, problems caused by $S$. frugiperda are still being experienced in the planting of this local corn variety in Bali $[12,13]$. Therefore, it is necessary to carry out a series of field-scale studies to evaluate the level of attack and the potential loss of yield as a result of this $S$. frugiperda attack. So that the results of this study provide information about the impact of these pests and can make decisions in controlling them wisely.

\section{MATERIALS AND METHODS}

\subsection{Study area}

This research was conducted on a field-scale located in Gianyar Regency, Bali. The corn land used belongs to local farmers with an area of 10 ha.

\subsection{Research design}

This study used 4 treatments and 6 replications with 10 samples/replications that were systematically determined. The plot units are $3 \times 3 \mathrm{~m}$ in size with a distance between the plots of $1 \mathrm{~m}$. The maize used were sweet and glutinous maize varieties with a spacing of 25 $\mathrm{cm} \times 65 \mathrm{~cm}$ with one perforated plant.

Table 1. Treatment in this study

\begin{tabular}{cc}
\hline Treatment & Remarks \\
\hline V1P1 & Sweet corn without $S$. frugiperda attack \\
V1P2 & Sweet corn is attacked by S. frugiperda \\
V2P1 & Glutinous without $S$. frugiperda attack \\
V2P2 & Glutinous corn is attacked by S. frugiperda \\
\hline
\end{tabular}

\begin{tabular}{|c|c|c|c|c|c|}
\hline U1 & U2 & U3 & U4 & U5 & U6 \\
\hline V1P1 & V1P2 & V2P1 & V2P2 & V1P1 & V1P2 \\
\hline V2P2 & V1P1 & V1P2 & V2P1 & V2P2 & V1P1 \\
\hline V2P1 & V2P2 & V1P1 & V1P2 & V2P1 & V2P2 \\
\hline V1P2 & V2P1 & V2P2 & V1P1 & V1P2 & V2P1 \\
\hline
\end{tabular}

Figure 1. Treatment plan

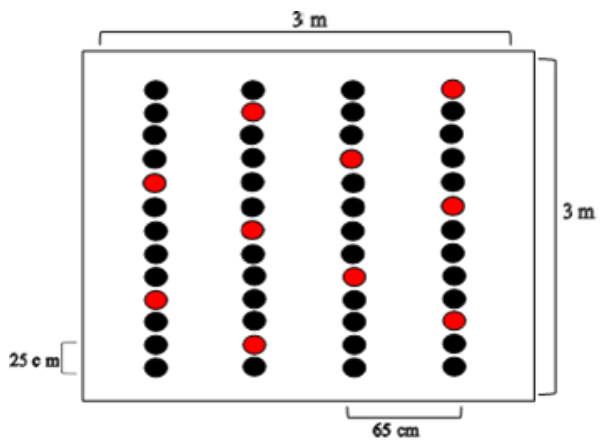

Figure 2. Observed sample scheme

\subsection{Observation method}

Observations were made once a week by directly observing the presence of $S$. frugiperda pests in each sample of the maize plant. The variables observed in this study are:

\subsubsection{Population development \& attack rate}

The number of $S$. frugiperda populations present in the sample plants was counted once a week to observe population development, and the findings were averaged. Observation of the level of attack was carried out by determining the attack rate (\%) using the equation [14], namely:

$P=\frac{a}{a+b} \times 100$

Note:

$P=$ the percentage of plants affected $(\%)$

$a=$ the number of plants attacked

$b=$ the number of plants observed

Furthermore, after knowing the percentage of plants attacked, it is then compared with the attack criteria table in Table 2.

Table 2. Attack level criteria

\begin{tabular}{ccc}
\hline No. & Attack percentage & Criteria \\
\hline 1 & $0 \%$ & Healthy \\
2 & $>0-10 \%$ & Very low \\
3 & $>10-20 \%$ & Low \\
4 & $>20-40 \%$ & Moderate \\
5 & $>40-60 \%$ & High \\
6 & $>60-100 \%$ & Very high \\
\hline
\end{tabular}

Source: Moekasan et al. [15]

\subsubsection{Decreased production}

Observation of the decline in production was carried out by taking a sample plant that was observed in each treatment plot and weighing it then converting it to hectares and comparing the results from plots of corn 
plants that were not attacked by $S$. frugiperda with the plots of plants that were attacked by $S$. frugiperda with the formula:

$H=\frac{a-b}{a} \times 100 \%$

Note:

$H=$ Decreased production $(\%)$

$a=$ Results from plots that were not attacked by $S$. frugiperda

$b=$ Results from plots infested with $S$. frugiperda

\subsection{Data analysis}

To determine the differences in each treatment, data were analyzed using SPSS 23.0 version software (IBM, USA) and then analyzed using the T-Test and a 5\% confidence interval.Data is displayed in the form of graphs, figures, and tables.

\section{RESULT AND DISCUSSION}

\subsection{Population development of S. frugiperda}

The results of our observations showed that in the treatment of sweet corn (V1P2) and glutinous corn (V2P2) which were attacked by $S$. frugiperda, the population began to be found in plants 2 weeks after planting (wap) (Fig 3). The population average was 5.37 on sweet corn and 6.53 on glutinous corn. The population continues to increase and the peak occurs at 5 wap with a population of 13.87 on sweet corn and 15.24 on glutinous corn. Furthermore, the larvae population decreased until the maize plant was 8 wap. Furthermore, at the age of 9 wap corn, no further $S$. frugiperda population development was found in the treatment of sweet corn (V1P1) and glutinous maize (V2P1). The maize variety sampling activity is shown in Fig 3.

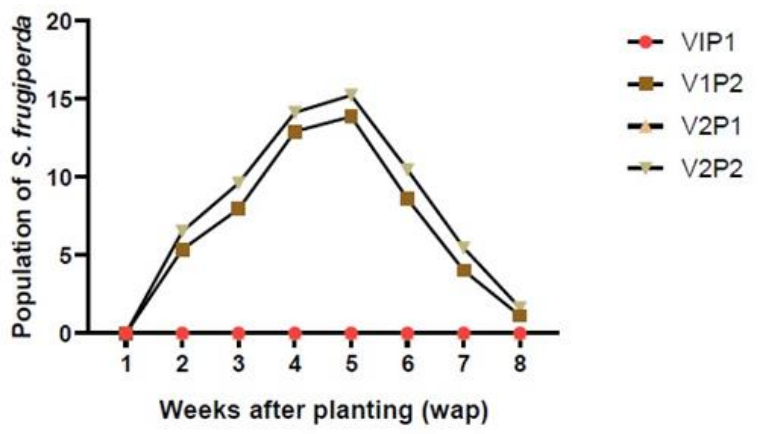

Figure 3. Population development of $S$. frugiperda in sweet and glutinous corn in field-scale trials.

The decline in the larvae population can be caused by various obstacles. According to Wahyuni et al. [16], food sufficiency, climate, competition, and natural enemies are environmental factors that significantly influence population growth and development, which in turn affects the natural decline in insect pest populations. Nutrient sources in the form of nectar or pollen can act as carbohydrates that can improve the fitness and reproductive output of adult Lepidoptera including $S$. frugiperda [17].

The life cycle of insect pests is another environmental element that influences their growth, development, and population density [18]. According to study, $S$. frugiperda has a high reproductive capability at $34^{\circ} \mathrm{C}$ and a high population expansion [19]. The population of $S$. frugiperda can develop well at an altitude of about 700850 masl (metres above sea-level) [5].

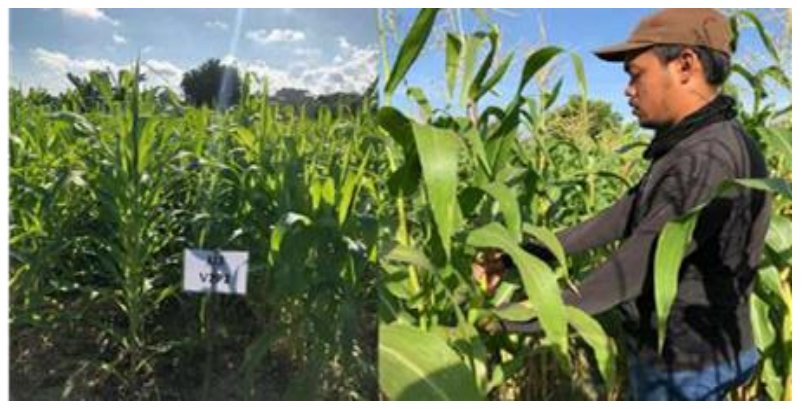

Figure 4. Sampling of $S$. frugiperda pests on maize plantations (Figure source: Authors)

\subsection{The correlation of population and $S$. frugiperda attack rate}

The results showed that the treatment of sweet corn (V1P2) and glutinous maize (V2P2) was attacked by S. frugiperda, the attack began to appear on plants aged 2 WAP with an average low attack rate of $16.93 \%$ in sweet corn and $17.09 \%$ on glutinous corn. The attack rate increases and peaks at 5 weeks after planting (wap) with a high attack rate of $46.73 \%$ for sweet corn and $49.79 \%$ for glutinous corn. Then, the attack decreases until the corn plant is 8 (wap) with an average attack rate of 31.15 . $\%$ in sweet corn and $33.65 \%$ in glutinous corn ( Fig. 5). Crop damage caused by armyworms, according to Arifin [20], can be impacted by population density and insect pest stages. S. frugiperda causes more severe plant damage during the vegetative period [21].

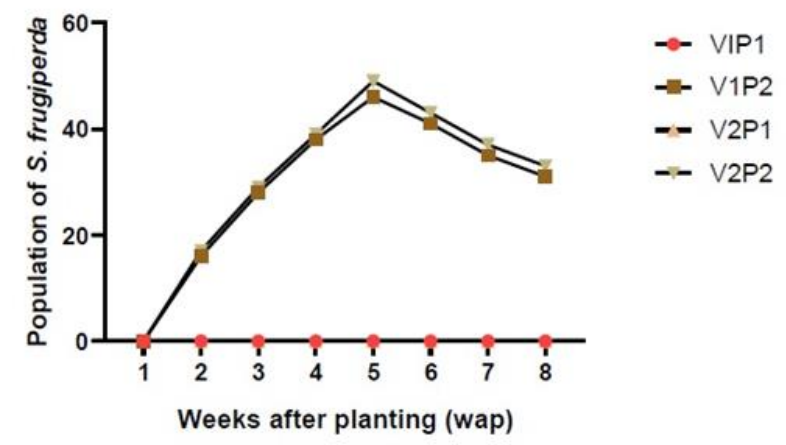

Figure 5. The level of attack rate on sweet and glutinous maize

The regression analysis results showed a relationship between the larval population and the attack rate of $S$. frugiperda and the relationship follows the following 
equation: $y=1.4122 x+22,657$ with a correlation coefficient (R2) of 0.4115 (Fig. 6). In our cases indicates, that each addition of the 1.4 larvae population of $S$. frugiperda can cause an increase in the attack rate by $22.65 \%$. The greater the pest population density, the greater the harm. The capacity to control pests can also have an impact on crop damage severity [22].

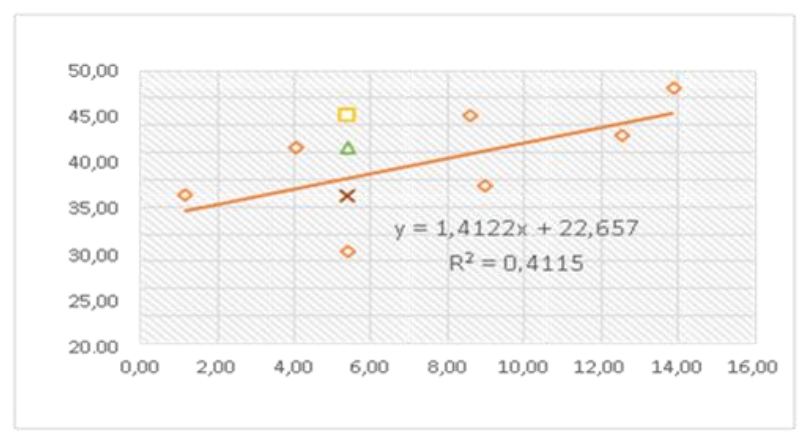

Figure 6. Population correlation with attack rate of $S$. frugiperda

\subsection{Potential decrease production of maize varieties in this study}

The analysis showed that the production of sweet corn that was not attacked by $S$. frugiperda (V1P1) was significantly different from that of sweet corn that was attacked by $S$. frugiperda (V1P2). The amount of yield decrease caused by $S$. frugiperda attack on sweet corn was $28.08 \%$. There were also significant differences in the treatment of glutinous maize that was not affected and glutinous corn that was attacked by $S$. frugiperda. The infection of $S$. frugiperda on glutinous maize resulted in a 25.04 percent yield decrease. A total population of $0.2-$ 0.8 larvae per plant drastically reduces productivity by 5 $20 \%$ [12].

Table 3. The decrease in yield was caused by $S$.

frugiperda attack on sweet and glutinous corn

\begin{tabular}{ccc|ccc}
\hline \multicolumn{3}{c|}{ Sweet Corn } & \multicolumn{3}{c}{ Glutinous corn } \\
\hline Treatment & $\begin{array}{c}\text { Wet } \\
\text { Weight } \\
\text { (ton/Ha) }\end{array}$ & $\begin{array}{c}\text { Decreased } \\
\text { yield (\%) }\end{array}$ & Treatment & $\begin{array}{c}\text { Wet } \\
\text { Weight } \\
\text { (ton/Ha) }\end{array}$ & $\begin{array}{c}\text { Decreased } \\
\text { yield (\%) }\end{array}$ \\
\hline V1P1 & $19.66^{\mathrm{a}}$ & 28.08 & $\mathrm{~V} 1 \mathrm{P} 1$ & $6.95^{\mathrm{a}}$ & 25.04 \\
V1P2 & $14.14^{\mathrm{b}}$ & & $\mathrm{V} 1 \mathrm{P} 2$ & $5.21^{\mathrm{b}}$ & 25 \\
\hline
\end{tabular}

Note: the numbers followed by different letters in the same column show a significant difference at the $5 \%$ level.

According to recent research, the amount of damage produced by $S$. frugiperda in 126 cornfields in ten districts of Karnataka during the wet season with a distributed equal infestation ranged from 44 to 100 percent [23]. Interestingly, the old larvae of $S$. frugiperda also have an affinity for cabbage which causes economic losses in China [24].

\section{CONCLUSIONS}

Treatment of sweet corn (V1P2) and glutinous maize (V2P2) which were attacked by $S$. frugiperda, the population began to be found in plants aged 2 (wap), the average population was 5.37 on sweet corn and 6.53 on glutinous corn. The population continues to increase and peaks at 5 (wap) with a population of 13.87 in sweet corn and 15.24 in glutinous corn, then the larva population decreases until the maize plant is $8 \mathrm{mst}$. 2 . The regression analysis shows the relationship between the larval population and the $S$. frugiperda attack rate, that is, each addition of 1.4 S. frugiperda larvae population causes an increase in the attack rate of $22.65 \%$. The yield decrease caused by S. frugiperda attack on sweet corn was $28.08 \%$ while it was $25.04 \%$ for glutinous corn.

Future research is still needed, especially information about the distribution of hosts from Family Gramineae and also the possibility of horticultural commodities, especially in the Province of Bali. Monitoring the presence of natural enemies associated with $S$. frugiperda is also very necessary for the integrated and environmentally friendly management of this pest [25]. In Bali Province, intensive field monitoring of $S$. frugiperda and ecological research is still needed [26].

\section{AUTHORS' CONTRIBUTIONS}

AAAASS, IKS, and IWS: conceived and developed the experiment, as well as managed and received financing for the research. IGFM, IKWY, and IWEKU carried out the experiment and analyzed the results. The paper was written by PAW. The published version of the work has been reviewed and approved by all authors.

\section{ACKNOWLEDGMENTS}

The authors would like to thank the Head of the Integrated Pest Management Laboratory at Udayana University for providing facilities and permission for the study. The authors would also like to thank I Gusti Bagus Putu Krisna Putra and I Gede Madu Sudana for their assistance with data collection and observation. The author would like to express gratitude to the Leading Research Study Program of 2020, with Contract Number: B/261/UN14.2.6.II/PT.01.03/2020, for supporting and funding this research.

\section{REFERENCES}

[1] G.O. Edmeades, W. Trevisan, B.M. Prasanna, H. Campos, Tropical Maize (Zea mays L.), in: Genet. Improv. Trop. Crop., Springer International Publishing, Cham, 2017, pp. 57-109. https://doi.org/10.1007/978-3-319-59819-2 3.

[2] Food and Agriculture Organization., Indonesia prepares for battle with Fall Armyworm, 2019. 
http://www.fao.org/indonesia/news/detailevents/en/c/1202177/ (accessed April 6, 2021).

[3] B. Prasanna, Maize in the Developing World: Trends , Challenges , and Opportunities, in: Agric. Food Secur. under Glob. Chang. Prospect. 2025/2050. IFPRI, 2009, pp. 26-38.

[4] G. Goergen, P.L. Kumar, S.B. Sankung, A. Togola, M. Tamò, First Report of Outbreaks of the Fall Armyworm Spodoptera frugiperda (J E Smith) (Lepidoptera, Noctuidae), a New Alien Invasive Pest in West and Central Africa, PLoS One. 11, 2016, pp. 1-9. doi.org/10.1371/journal.pone.0165632.

[5] A. Aripin, N. Lubis, R. Anwar, B.P.W. Soekarno, B. Istiaji, D. Sartiami, D. Herawati, The Attack of the Corn Armyworm (Spodoptera Frugiperda) on Corn Plants in Petir Village, Daramaga District, Bogor Regency and Its Control Potential Using Metarizhium Riley (Coray Wood Corn (Spodoptera Frugiperda) Caterpillars (in Bahasa) in Corn Crop, J. Pus. Inov. Masy, 2020, pp. 931-939.

[6] CABI, FAO, Community-Based Fall Armyworm (Spodoptera frugiperda) Monitoring, Early Warning and Management, Training of Trainers Manual, First Edit, The Food and Agriculture Organization of the United Nationd and CAB International, 2019.

[7] S.S. Girsang, S.E. Nurzannah, M.A. Girsang, R. Effendi, The distribution and impact of fall army worm ( Spodoptera frugiperda) on maize production in North Sumatera, IOP Conf. Ser. Earth Environ. Sci. 484, 2020, pp. 1-8. https://doi.org/10.1088/1755-1315/484/1/012099.

[8] M. Syukur, A. Rifianto, Jagung Manis, in: Penebar Swadaya, Penebar Swadaya, Jakarta, Indonesia, 2013.

[9] M. Muhsanati, A. Syarif, S. Rahayu, The Effect of Several Tithonia Compost Doses on the Growth and Yield of Sweet Corn Plants (Zea mays saccharata) (in Bahasa), Universitas Andalas, 2008, http://repository.unand.ac.id/2532/.

[10] S. Widowati, S. Santosa, Suarni, Mutu gizi dan sifat fungsional jagung., in: Pros. Semin. Dan Lokakarya Nas. Jagung., Pusat Penelitian Tanaman Pangan. Badan Litbang Pertanian, 2006.

[11] A.A. Rouf, D. Zubair, M. Walangadi, S. Antu, Pengkajian pemurnian benih jagung pulut di provinsi Gorontalo., in: Pros. Pekan Serelia Nas., Gorontalo, 2010.

[12] I.W. Supartha, A.A.A.A.S. Sunari, I.G.P.B. Krisna, I.K.W. Yudha, P.A. Wiradana, Invasion, Population Development and Attack intensity of the fall armyworm Spodoptera frugiperda J.E. Smith (Lepidoptera: Noctuidae) on two variety corn in Serongga Village, Gianyar Regency, Bali Indonesia, Technol. Rep. Kansai Univ. 10, 2021, pp. 645-654.

[13] I.W. Supartha, I.W. Susila, A.A.A.A.S. Sunari, I.G.F. Mahaputra, I.K.W. Yudha, P.A. Wiradana, Damage characteristics and distribution patterns of invasive pest, Spodoptera frugiperda (J.E Smith) (Lepidoptera: Noctuidae) on maize crop in Bali, Indonesia, Biodiversitas J. Biol. Divers ,2021, pp. 3378-3389.

https://doi.org/10.13057/biodiv/d220645.

[14] S. Putrasamedja, W. Setiawati, L. Lukman, A. Hasyim, Appearance of Several Shallot Clones and Their Relationship with Intensity of Attack of Plant Pest Organisms, J. Hortik., 2016, pp. 349-359. https://doi.org/10.21082/jhort.v22n4.2012.p349$\underline{359}$.

[15] T. Moekasan, Penerapan Ambang Pengendalian Organisme Pengganggu Tumbuhan pada Budidaya Bawang Merah dalam Upaya Mengurangi Penggunaan Pestisida, J. Hortik, 2012, pp. 47-56. https://doi.org/10.21082/jhort.v22n1.2012.p47-56.

[16] S. Wahyuni, I.W. Supartha, R. Ubaidillah, I.N. Wijaya, Parasitoid community structure of leaf miner Liriomyza spp. (Diptera: Agromyzidae) and the rate of parasitization on vegetable crops in Lesser Sunda Islands, Indonesia, Biodiversitas, 2017 , pp.593-600. https://doi.org/10.13057/biodiv/d180221.

[17] L. He, S. Jiang, Y. Chen, K.A.G. Wyckhuys, S. Ge, W. He, X. Gao, K. Wu, Adult nutrition affects reproduction and flight performance of the invasive fall armyworm, Spodoptera frugiperda in China, J. Integr. Agric., 2021, pp. 715-726. https://doi.org/10.1016/S2095-3119(20)63198-7.

[18] D.D. Nuriyanti, I. Widhiono, A. Suyanto, FaktorFaktor Ekologis yang Berpengaruh terhadap Struktur Populasi Kumbang Badak (Oryctes rhinoceros L.), Biosfera, 2017, pp. 13-21. https://doi.org/10.20884/1.mib.2016.33.1.310.

[19] K. Ashok, V. Balasubramani, J. Kennedy, V. Geethalakshmi, P. Jeyakumar, N. Sathiah, Effect of elevated temperature on the population dynamics of fall armyworm, Spodoptera frugiperda, J. Environ. Biol, 2021, pp. 1098-1105. https://doi.org/10.22438/jeb/42/4(SI)/MRN-1525a.

[20] M. Arifin, Bioinsektisida SINPV untuk mengendalikan ulat grayak mendukung swasembada kedelai, Pengemb. Inov. Pertan, 2011, pp.2419-31. 
[21] Y.A. Trisyono, S. Suputa, V.E.F. Aryuwandari, M. Hartaman, J. Jumari, Occurrence of Heavy Infestation by the Fall Armyworm Spodoptera frugiperda, a New Alien Invasive Pest, in Corn Lampung Indonesia, J. Perlindungan Tanam. Indones, 2019, pp.156-160. https://doi.org/10.22146/jpti.46455.

[22] C.L. Kaparang, J. Pelealu, C.L. Salaki, Populasi dan Intensitas Serangan Paraeucosmetus pallicornis Pada Tanaman Padi Di Kabupaten Minahasa Selatan, EUGENIA., 2011, pp. 171-178 https://doi.org/10.35791/eug.17.3.2011.3540. .

[23] O. Navik, A.N. Shylesha, J. Patil, T. Venkatesan, Y. Lalitha, T.R. Ashika, Damage, distribution and natural enemies of invasive fall armyworm Spodoptera frugiperda (J. E. smith) under rainfed maize in Karnataka, India, Crop Prot., 2021. https://doi.org/10.1016/j.cropro.2021.105536.
[24] W. Wang, P. He, Y. Zhang, T. Liu, X. Jing, S. Zhang, The Population Growth of Spodoptera frugiperda on Six Cash Crop Species and Implications for Its Occurrence and Damage Potential in China, Insects., 2020, pp. 1-14. https://doi.org/10.3390/insects11090639.

[25] R.D. Harrison, C. Thierfelder, F. Baudron, P. Chinwada, C. Midega, U. Schaffner, J. van den Berg, Agro-ecological options for fall armyworm (Spodoptera frugiperda JE Smith) management: Providing low-cost, smallholder friendly solutions to an invasive pest, J. Environ. Manage., 2019, pp.318-330.

https://doi.org/10.1016/j.jenvman.2019.05.011.

[26] J. Kim, H.Y. Nam, M. Kwon, H.J. Kim, H.J. Yi, S. Haenniger, M. Unbehend, D.G. Heckel, Development of a simple and accurate molecular tool for Spodoptera frugiperda species identification using LAMP, Pest Manag. Sci., 2021, pp.31453153. https://doi.org/10.1002/ps.6350. 